Research article

\title{
EFFECT OF ORGANIC SELENIUM AND IODINE SUPPLEMENTATION ON SELENIUM AND THYROID HORMONES STATUS OF LACTATING EWES AND LAMBS
}

\author{
KONEČNÝ Roman*, HASOŇOVÁ Lucie, TRÁVNÍČEK Jan, SAMKOVÁ Eva, \\ HLADKÝ Jan, KŘÍŽOVÁ Zuzana
}

Faculty of Agriculture, University of South Bohemia in České Budějovice, Studentská 13, České Budějovice, Czech Republic

(Received 11 February; Accepted 22. June 2015)

\begin{abstract}
The aim of this research was to determine the influence of 56-days (from day 4 to day 60 post partum) of simultaneous supplementation of selenium (Se) and iodine (I) enriched Chlorella algae on blood and urine Se concentrations and thyroid hormone levels in ewes and lambs. The study included 18 Šumava sheep ewes and their lambs divided into three groups (CON, HSe, HSeI). Selenium and I content in the diet of ewes measured 0.2 and $0.7 \mathrm{mg}(\mathrm{CON}), 0.4$ and $0.7 \mathrm{mg}$ (HSe), 0.4 and $1.3 \mathrm{mg}(\mathrm{HSeI})$ per $\mathrm{kg}$ of dry matter. During the experimental period a significantly higher blood serum Se concentration was determined in ewes of the HSeI group $(\mathrm{P}<0.001)$ and urine $(\mathrm{P}<$ 0.01). A significantly higher $(\mathrm{P}<0.001)$ blood serum Se concentration was found also in lambs of the HSeI group. The highest Se concentration in the blood serum was recorded in ewes $(128.0 \mu \mathrm{g} / \mathrm{L})$ and lambs $(74.2 \mu \mathrm{g} / \mathrm{L})$ on the 26th day of the experiment. The results demonstrate a higher utilization of Se administered in the organic form accompanied by a higher intake of I applied also in the organic form. Plasma thyroid hormone levels in ewes were not explicitly affected by higher Se and I supplementation. A higher Se concentration in the lambs' blood serum led to significantly higher $(\mathrm{P}<$ $0.05) \mathrm{T} 3$ levels up to 30 days post birth.
\end{abstract}

Key words: Chlorella algae, iodine, selenium, sheep, thyroxine, triiodothyronine

\section{INTRODUCTION}

Iodine (I) and selenium (Se) are micronutrients essential for normal thyroid function and play a vital role in maintaining good health in animals. Iodine is a component of thyroxine (T4) and triiodothyronine (T3) hormones. Selenium in selenoenzymes iodothyronine deiodinases plays a crucial role in the activation or inactivation of both thyroid hormones [1,2]. Moreover, Se is found as selenocysteine in the catalytic centre of enzymes protecting the thyroid gland from free radical damage $[3,4]$.

\footnotetext{
*Corresponding author: e-mail: konecnyroman@centrum.cz
} 
Several studies have examined how dietary I or Se intake affects Se status and thyroid gland function in different animal species. For example, I intake in the diet for growing kids $(0.14-0.29 \mathrm{mg}$ per head/day) along with I administration per os $(0.2-0.3 \mathrm{mg}$ per head/day) led to a significant decrease in Se concentration in the blood $(88 \mu \mathrm{g} / \mathrm{L})$ and glutathione-peroxidase (GSHPx) activity in comparison with the group without I supplementation. No significant differences were found in T3 or T4 levels [5].

Numerous studies have demonstrated the relationship between Se supplementation, its concentration and GSHPx activity in different tissues. For example, Misurova et al. [6] found out, that per os Se supplementation (0.43 $\mathrm{mg}$ per head/day) significantly increased Se concentration in the blood $(177 \mu \mathrm{g} / \mathrm{L})$ and GSHPx activity in goats. Chadio et al. [7] and Travnicek et al. [8] confirmed these results in ewes and lambs.

The form of I and Se supplementation in animal diets can be either inorganic [9] or organic [10]. It is generally accepted that the inorganic form is not utilized as efficiently as the organic form [6]. Moreover, organic forms of Se are absorbed and retained more readily by ruminants than inorganic forms [11]. Therefore, recent studies have focused on comparing both these forms $[12,13]$.

Although there is enough information available on the effects of either Se or I deficiency on the development of some human and animal diseases, there is far less information about their mutual interactions [14]. There is a lack of studies about the impacts of co-administration of Se and I in sheep, particularly for organic forms.

The aim of the present study was to evaluate Se status and thyroid hormone levels in ewes and their lambs during administration of I and Se in the organic form.

\section{MATERIALS AND METHODS}

\section{Animal, feeding and experimental design}

The 56-day experiment was conducted at the Faculty of Agriculture of The University of South Bohemia in České Budějovice. The Animal Care and Use Council of the University of South Bohemia approved the use and treatment of animals in this study.

Eighteen pregnant ewes of Šumava sheep (dual-purpose breed) were divided into three groups (control - CON; experimental - HSe, HSeI; with 6 animals in each group), which were balanced for parity (4) and mean weight $(54.5 \pm 3.0 \mathrm{~kg})$. The ewes were stabled in a conventional pen $(1.6 \mathrm{~m} 2 /$ head) with free access to water.

The composition of the feed ration is shown in Table 1. All ewes received an identical diet during the pregnancy period and up to the first 3 days post partum. From the 4th to the 60th day post partum (experimental period) the ewes received the feed with a different addition of I and Se enriched algae Chlorella supplement. The supplement contained $109.4 \mathrm{mg}$ I and $27.0 \mathrm{mg}$ Se per $1 \mathrm{~kg}$ dry matter (DM) for group CON, $109.4 \mathrm{mg} \mathrm{I}$ and $54.3 \mathrm{mg}$ Se for group HSe, and $211.1 \mathrm{mg} \mathrm{I}$ and $54.3 \mathrm{mg}$ Se for group HSeI. 
Table 1. Intake of iodine (I) and selenium (Se) per ewe/day in the feed and supplement dry matter (DM)

\begin{tabular}{|c|c|c|c|c|c|c|c|c|c|c|c|c|}
\hline \multirow{3}{*}{ Period } & & & \multicolumn{3}{|c|}{ Feed* } & \multicolumn{3}{|c|}{ Supplement ${ }^{\dagger}$} & \multicolumn{4}{|c|}{ Total content } \\
\hline & \multicolumn{2}{|c|}{ Groups } & DM & Se & I & DM & Se & I & Se & I & $\mathrm{Se}$ & I \\
\hline & & & $(\mathrm{kg})$ & \multicolumn{2}{|c|}{ (mg) } & $(\mathrm{kg})$ & \multicolumn{2}{|c|}{ (mg) } & \multicolumn{2}{|c|}{ (mg) } & \multicolumn{2}{|c|}{$(\mathrm{mg} / \mathrm{kg} \mathrm{DM})$} \\
\hline \multirow{3}{*}{$\mathrm{BE}$} & $\mathrm{CON}$ & $(n=6)$ & 1.3 & 0.1 & 0.2 & 0 & 0 & 0 & 0.1 & 0.2 & 0.08 & 0.15 \\
\hline & HSe & $(\mathrm{n}=6)$ & 1.3 & 0.1 & 0.2 & 0 & 0 & 0 & 0.1 & 0.2 & 0.08 & 0.15 \\
\hline & HSeI & $(n=6)$ & 1.3 & 0.1 & 0.2 & 0 & 0 & 0 & 0.1 & 0.2 & 0.08 & 0.15 \\
\hline \multirow{3}{*}{$\mathrm{E}$} & $\mathrm{CON}$ & $(\mathrm{n}=6)$ & 1.7 & 0.1 & 0.3 & 0.009 & 0.2 & 1.0 & 0.3 & 1.3 & 0.2 & 0.7 \\
\hline & HSe & $(\mathrm{n}=6)$ & 1.7 & 0.1 & 0.3 & 0.009 & 0.5 & 1.0 & 0.6 & 1.3 & 0.4 & 0.7 \\
\hline & HSeI & $(\mathrm{n}=6)$ & 1.7 & 0.1 & 0.3 & 0.009 & 0.5 & 1.9 & 0.6 & 2.2 & 0.4 & 1.3 \\
\hline
\end{tabular}

$\mathrm{BE}$ - before experiment (pregnancy period and the first 3 days post partum);

$\mathrm{E}$ - experiment (4 to 60 days post partum); DM $=$ dry matter; $* 1500 \mathrm{~g}$ meadow hay, $240 \mathrm{~g}$ lucerne granules and $270 \mathrm{~g}$ oat groats; ${ }^{\dagger}$ Se and I enriched alga Chlorella

The algae were produced by heterotrophic cultivation at the Microbiological Institute of the Czech Academy of Sciences in Třeboň [15].

The average birth weight of lambs ( $\mathrm{n}=18,6$ per group) was $4.6 \pm 0.5 \mathrm{~kg}$ and at the end of the experiment (on the 60th day of the lambs' age) the weight was $15.4 \pm 1.8 \mathrm{~kg}$. The lambs were housed with their mothers. They were fed only with maternal milk.

\section{Sampling and analysis}

Urine samples were collected from the ewes on the day of parturition (within 24 hours post partum), and on day 60 post partum with a bladder catheter.

Blood samples were taken from the vena jugularis on the day of parturition (within 24 hours post partum) and on day 10, 30, and 60 post partum in ewes, on the day of birth, and on day 10, 30, 60 in lambs. In total, 36 urine samples, 72 blood samples from ewes, and 72 blood samples from lambs were collected.

Selenium concentration was determined in the blood serum and urine by neutron activation analysis and spectrofluorimetry according to Kvicala et al. [16].

Iodine in the ewes and lambs blood plasma was determined on the basis of alkaline ashing by a spectrophotometric method according to Sandell-Kolthoff [17].

Plasma concentrations of total T3 and T4 hormones were assessed by commercial radioimmunoassay kits (Immunotech, Prague, Czech Republic).

Dry matter content of the feed ration was determined after drying at $105^{\circ} \mathrm{C}$ for 24 hours in a forced air-drying oven.

\section{Statistical analysis}

The data were statistically analysed using the program Statistica CZ 6.1 (Statsoft CZ). Dependent variables were estimated using the following (ANOVA) model: Yijk $=\mu+$ 
$\mathrm{Gi}+\mathrm{Pj}+$ eijk, where Yijk $=$ Se concentrations in blood serum and urine $(\mu \mathrm{g} / \mathrm{L}), \mathrm{T} 3$, T4 levels in blood plasma (nmol/L); $\mu=$ mean; $\mathrm{Gi}=\operatorname{group}(\mathrm{i}=\mathrm{CON}, \mathrm{HSe}, \mathrm{HSeI})$; $\mathrm{Pj}=$ period of experiment $(\mathrm{j}=1,10,30,60$ days $)$, and eijk $=$ residual error. Tukey and Student t-test were used for the comparison of groups and period of experiment.

\section{RESULTS}

\section{Blood serum selenium concentration in ewes and their lambs}

The effect of dietary I and Se on serum Se concentration in ewes is shown in Fig. 1A. The addition of both microelements into the feed ration led to a Se concentration increase in the blood serum of ewes, especially in the HSeI group. A significant increase of Se in the blood serum $(83.5 \mu \mathrm{g} / \mathrm{L} ; \mathrm{P}<0.001)$ was determined on day 10 post partum (the 6th day of the experiment) in the group with a high I and Se supplementation. The increase of Se continued until day 30 post partum $(128.0 \mu \mathrm{g} / \mathrm{L}$; $\mathrm{P}<0.001)$ when the concentration the in the serum was by $197 \%$ higher compared to the initial values. On the last day of the experiment (day 60 post partum) a further increase of Se concentration was not measured. In the control group (CON) with recommended norm intake of both microelements, the increase of Se in the blood serum during the whole experiment was gradual until the end of the experiment. Significantly lower $(\mathrm{P}<0.001)$ values of Se concentration were detected from day 10 post partum in comparison to the HSeI group. On this day the increase of Se amounted to $22.7 \%(51.9 \mu \mathrm{g} / \mathrm{L} ; \mathrm{P}<0.01)$ and at the end of the experiment $74.9 \%(74.0 \mu \mathrm{g} / \mathrm{L}$; $\mathrm{P}<0.001)$. Similar changes in blood serum Se concentration were detected in the HSe group, in which only Se was added to the feed ration. During the whole experiment significant differences between the CON and the HSe group were not recorded.

Before the experiment a markedly lower Se concentration in the lambs' blood serum of all groups (CON 28.7; HSe 28.2; HSeI $30.0 \mu \mathrm{g} / \mathrm{L}$ ) was observed (Fig. 1B). Selenium and I supplementation of ewes led to a gradual increase in serum Se concentration in their lambs (Fig. 1B). Concerning the dynamics of Se concentration in lambs, in the
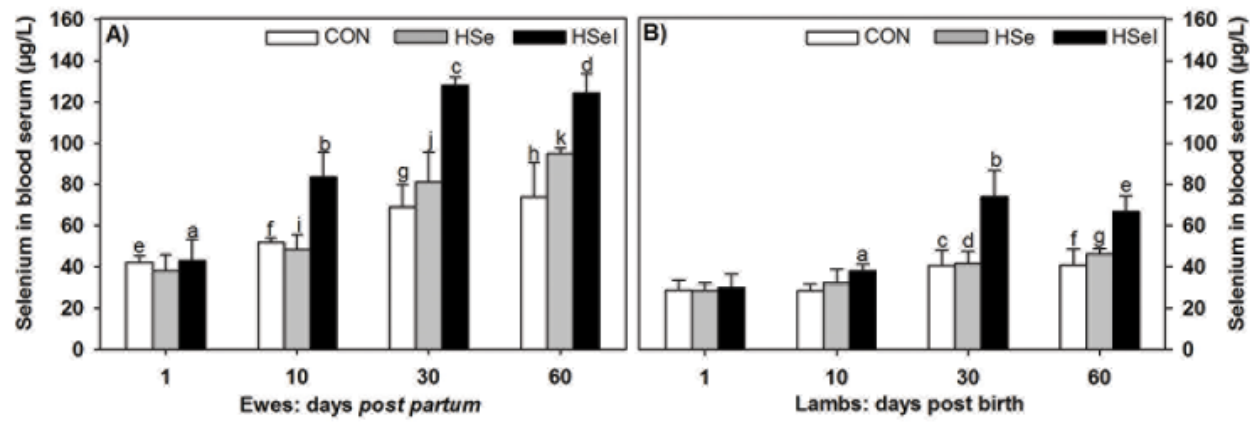

Figure 1. Selenium concentration in sera of $\mathbf{A}$ ) ewes and $\mathbf{B}$ ) their lambs with different $\mathrm{I}$ and Se intake from 4 days post partum or birth.

CON (control group; $0.2 \mathrm{mg} \mathrm{Se}+0.7 \mathrm{mg} \mathrm{I} / \mathrm{kg} \mathrm{DM} ; \mathrm{n}=6$ ), HSe (0.4 mg Se+0.7 mg I/ kg DM; $\mathrm{n}=6) ;$ HSeI $(0.4 \mathrm{mg} \mathrm{Se}+1.3 \mathrm{mg} \mathrm{I} / \mathrm{kg} \mathrm{DM} ; \mathrm{n}=6)$; Results are expressed as mean \pm standard

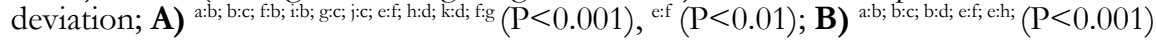


HSeI group a rapid and significant $(\mathrm{P}<0.001)$ increase from the 10 th $(38.0 \mu \mathrm{g} / \mathrm{L})$ to the 30th day of the lambs' age $(74.2 \mu \mathrm{g} / \mathrm{L})$ was observed, which was followed by a slight and insignificant $(9.9 \%)$ decrease on the 60th day. Also the Se concentration was significantly $(\mathrm{P}<0.001)$ higher in lambs of HISe group.

\section{Selenium content in the ewes' urine}

Before the experiment no significant differences were observed in the ewes' urine Se content (CON 16.4; HSe 15.8; HSeI $16.0 \mu \mathrm{g} / \mathrm{L})$. At the end of the experimental period a significantly higher $(45.8 \mu \mathrm{g} / \mathrm{L} ; \mathrm{P}<0.01)$ urine Se content was recorded in the HSeI group compared to group CON $(21.2 \mu \mathrm{g} / \mathrm{L})$ and HSe $(28.5 \mu \mathrm{g} / \mathrm{L})$.

\section{Levels of thyroid hormones in blood plasma}

Until the beginning of the experiment no significant differences in blood plasma levels of T3 and T4 were observed (Fig. 2). During the experimental period a gradual decrease of T3 level was recorded, which reached a statistical significance for all groups on the 60th day post partum (CON, HSeI $(\mathrm{P}<0.01)$; HSe $(\mathrm{P}<0.05)$. Plasma T4 level in all ewes showed a tendency to decrease as well, which temporarily reached statistical significance $(\mathrm{P}<0.05)$ only on the 30 th day post partum in the control group $(\mathrm{CON})$ with the recommended norm intake of Se $(0.2 \mathrm{mg} \mathrm{Se} / \mathrm{kg} \mathrm{DM})$.

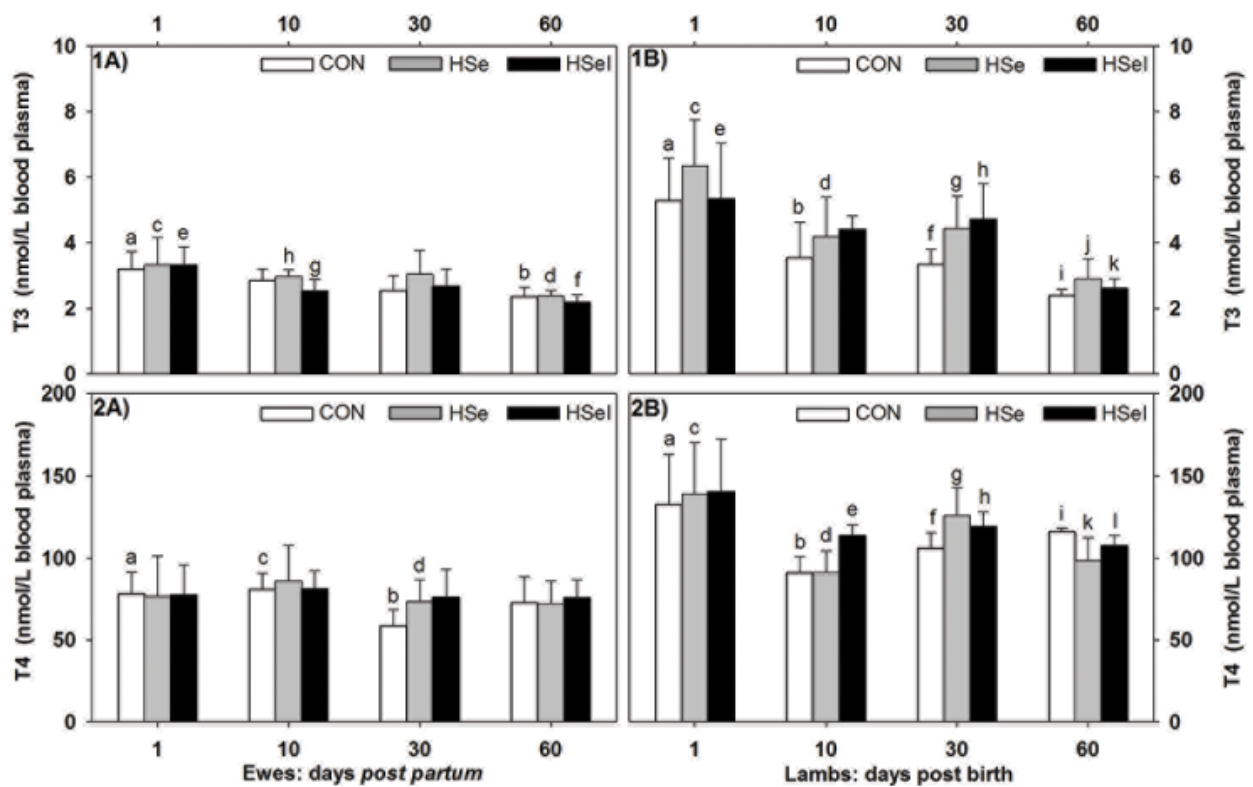

Figure 2. Effect of different I and Se intake on plasma 1) T3 and 2) T4 levels of A) ewes and B) their lambs supplemented from 4 days post partum or birth .

CON (control group; $0.2 \mathrm{mg} \mathrm{Se}+0.7 \mathrm{mg} \mathrm{I} / \mathrm{kg}$ DM; $\mathrm{n}=6$ ), HSe $(0.4 \mathrm{mg} \mathrm{Se}+0.7 \mathrm{mg} \mathrm{I} / \mathrm{kg} \mathrm{DM}$; $\mathrm{n}=6) ; \mathrm{HSeI}(0.4 \mathrm{mg} \mathrm{Se}+1.3 \mathrm{mg} \mathrm{I} / \mathrm{kg} \mathrm{DM} ; \mathrm{n}=6)$; Results are expressed as mean \pm standard

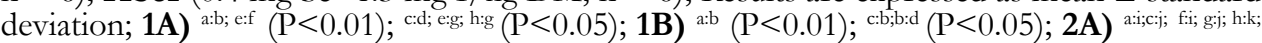

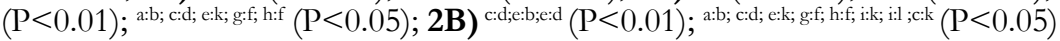


Similarly as in ewes, no significant differences were observed in lambs blood plasma T3 and T4 levels before the experiment (Fig. 2). From 4 to 60 days of age lambs of the control group recorded a linear and significant $(\mathrm{P}<0.01)$ decrease in plasma T3 levels. In the experimental groups of lambs the decline was slow and significant at the end of the experiment (HSe $(\mathrm{P}<0.01)$; HSeI $(\mathrm{P}<0.05))$. Among the high Se supplemented groups (HSe, HSeI) significantly higher blood serum Se concentration in the HSeI group was accompanied by an insignificantly higher plasma T3 level up to the 30th day post birth. In the case of T4 lower values were observed in all groups of lambs at the end of the experiment, but statistically significant $(\mathrm{P}<0.05)$ was only in the HSe group (Fig. 2). Higher Se supplementation of ewes (HSe, HSeI) resulted in a significantly higher $(\mathrm{P}<0.05) \mathrm{T} 4$ level on the 30th day of the age of lambs and significantly lower $(\mathrm{P}<0.05)$ on the 60 th day of age compared to the lambs of ewes supplemented with the recommended intake of $\mathrm{Se}(\mathrm{CON})$. A significant difference $(\mathrm{P}<0.01)$ between experimental groups was observed only on the 10th day after birth.

\section{DISCUSSION}

The optimal concentration of Se in the blood serum of ewes is $120-150 \mu \mathrm{g} / \mathrm{L}$ [18] while values from $25-50 \mu \mathrm{g} / \mathrm{L}$ are considered deficient [19]. In the submitted study the concentration of Se in the blood serum of ewes before the experiment was not optimal in any of the three groups $(42.3 ; 38.1 ; 43.1 \mu \mathrm{g} / \mathrm{L})$ as a result of its low concentration in the basic feed ration $(0.08 \mathrm{mg} / \mathrm{kg} \mathrm{DM})$. During the experiment launched on the 4 th day post partum the ewes in the control group $(\mathrm{CON})$ were given the recommended norm amount of I $(0.7 \mathrm{mg} / \mathrm{kg} \mathrm{DM})$ and $\mathrm{Se}(0.2 \mathrm{mg} / \mathrm{kg} \mathrm{DM})$. In the HSe group the adequate intake of I and Se was raised by $100 \%$. In the third group (HSeI) the intake of I concurrently was raised by $85.7 \%$ and Se by $100 \%$ in comparison to NRC requirements [20].

An increased blood serum Se concentration in the ewes with high I and Se (HSeI) intake to the 60th day post partum shows the influence I on Se utilisation and is in accordance with Guyot et al. [9] and Aghwan et al. [21], who found a synergistic relationship between I and Se metabolism when both microelements were supplemented simultaneously. Higher I supplementation in HSeI group also led to a significant $(\mathrm{P}<$ 0.01) increase of Se content in urine compared to the group HSe.

In the newborn lambs low serum Se concentrations (CON 28.7; HSe 28.2; HSeI $30.0 \mu \mathrm{g} / \mathrm{L})$ were observed. Ghany-Hefnawy et al. [22] reported that such a low serum Se status reflected insufficient levels of Se in the diet of mothers and its low transplacental transfer. At the beginning of the experiment the changes in lambs' serum Se concentrations were recorded, which corresponded to the dynamics of Se in their mothers.

A significant increase of Se concentration in the blood serum of ewes and their lambs corresponds to the dynamics of I concentration in the blood plasma of lambs (Fig. 
3B). Excessive I supplementation of lactating ewes led to a high I concentration in milk. Such excessive I intake disrupts the oxidative and antioxidative balance in the thyroid gland [23]. To compensate for this imbalance a proportional amount of selenoenzyme GSHPx is required. It can be assumed that a high I concentration in the milk led to a higher Se utilisation in suckling lambs of the HSeI group. In addition, in this group no significant Se decrease after 30 days post birth was associated with a significant decrease of I in the blood plasma (Fig. 3B), which was caused by the decrease of I concentration in milk with progressing lactation of the ewes.
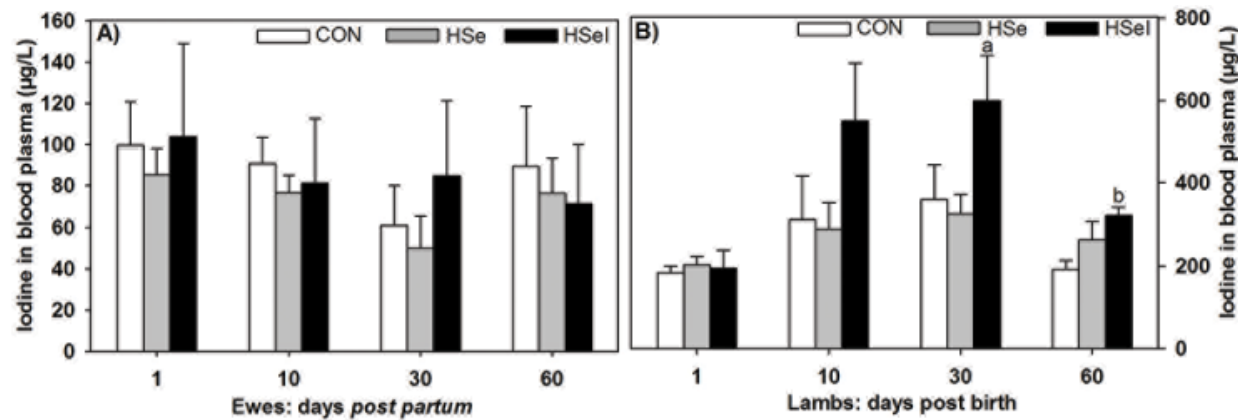

Figure 3. Iodine concentration in blood plasma of $\mathbf{A}$ ) ewes and $\mathbf{B}$ ) their lambs with different I and Se intake from 4 days post partum or birth. CON (control group; $0.2 \mathrm{mg} \mathrm{Se}+0.7 \mathrm{mg} \mathrm{I} / \mathrm{kg}$ DM; $\mathrm{n}=6)$, HSe (0.4 mg Se+0.7 mg I/ kg DM; $\mathrm{n}=6)$; HSeI $(0.4 \mathrm{mg} \mathrm{Se}+1.3 \mathrm{mg} \mathrm{I} / \mathrm{kg} \mathrm{DM} ; \mathrm{n}$ $=6)$; Results are expressed as mean \pm standard deviation; $\mathbf{B}){ }^{\text {a:b }}(\mathrm{P}<0.001)$

Awadeh et al. [24] and Bik [25] found out that Se supplementation has a positive effect on T3 level in cows and ewes. In our experiment a higher nutritional dosage of Se did not result in a significantly higher plasma T3 level. The same findings with the same result were reported by Qin et al. [26], who did not find any influence of Se supplementation on blood serum T3 level in Cashmere goats. When comparing the T3 (Fig. 2) level between experimental groups (HSe, HSeI), which differed only in I intake, during the experimental period in the HSeI group a lower T3 level was recorded $(\mathrm{P}<$ 0.05 ) only the 10 th day post partum, although this group had significantly $(\mathrm{P}<0.001)$ higher Se concentrations in the blood serum (Fig. 1A). The lower plasma T3 level of the HSeI group was probably due to the higher I concentration in the blood plasma (Fig. 3A) as reported by Wichtel et al. [27]. However, this result is contrary to Guyot et al. [9], who reported a higher blood T3 level in cows with high I and Se supplementation. Guyot et al. [9] also observed in their study with combined I and Se supplementation in cows, that a high I $(5.45 \mathrm{mg} / \mathrm{kg} \mathrm{DM})$ and Se $(0.45 \mathrm{mg} / \mathrm{kg} \mathrm{DM})$ diet resulted in a decrease of blood T4 level. In our trial high I and Se supplementation did not lead to significant decrease of blood plasma T4 level. These findings are in agreement with Qin et al. [26], who reported that blood serum T4 level was significantly enhanced $(\mathrm{P}<$ 0.05 ) only by increasing I supplementation, but no interactions between I and Se were observed for T4 levels. 
In lambs a decrease of thyroid hormones level was recorded until 60 days of age. Such decrease is consistent with the results of Head et al. [28] and Hewnavy et al. [29] and corresponds to ontogenetic dynamic thyroid hormones levels in blood plasma [30]. In contrast with the results of Chadio et al. [7] and Kumar et al. [31] who did not notice any effect of Se supplementation on lambs thyroid hormone levels, in our experimental period higher Se supplementation in ewes of HSe and HSeI group resulted in significantly higher $(\mathrm{P}<0.05)$ lamb plasma thyroid hormones levels up to 30 days post birth. After the 30th day post birth, a significant decline $(\mathrm{P}<0.05)$ only in plasma T4 level was observed compared to the group with the recommended intake of $\mathrm{Se}(\mathrm{CON})$.

\section{CONCLUSIONS}

Our results show that in Se deficient lactating ewes and their offspring a higher supplementation of Se and I in an organic form led to its higher utilisation, manifested by a significantly higher Se concentration in the blood serum. In addition, higher supplementation of organic I lead to significantly higher Se content in the ewes' urine. The ewes thyroid hormone levels showed did not seem to be explicitely influenced by higher Se and I supplementation. But a higher Se concentration in the lambs' blood serum affected the postnatal dynamics of the thyroid hormones within 30 days after birth.

\section{Acknowledgements}

This study was supported by the project of the Grant Agency of the University of South Bohemia in České Budějovice (GAJU 011/2013/Z; GAJU 152/2014/Z) and the Project of Ministry of Agriculture of the Czech Republic (NAZV QJ 1510336).

\section{REFERENCES}

1. Bianco AC, Salvatore D, Gereben B, Berry MJ, Larsen PR: Biochemistry, cellular and molecular biology, and physiological roles of the iodothyronine selenodeiodinases. Endocr Rev 2002, 23: 38-89.

2. Lu J, Holmgren A: Selenoproteins. J Biol Chem 2009, 284: 723-727.

3. Triggiani V, Tafaro E, Giagulli VA, Sabba C, Resta F, Licchelli B, Guastamacchia E: Role of iodine, selenium and other micronutrients in thyroid function and disorders. Endocr Metab Immune Disord Drug Targets 2009, 9: 277-294.

4. Valčić O, Jovanović I, Milanović S, Gvozdić D: Selenium status of feedstuffs and grazing ewes in Serbia, Acta Vet Beograd, 2013, 63: 665-675.

5. Pavlata L, Slosarkova S, Fleischer P, Pechova A: Effects of increased iodine supply on the selenium status of kids. Vet Med-Czech 2005, 50: 186-194.

6. Misurova L, Pavlata L, Pechova A, Dvorak R: Effect of a long-term peroral supplementation with sodium selenite and selenium lactate-protein complex on selenium status in goats and their kids. Vet Med-Czech 2009, 54: 324-332. 
7. Chadio SE, Kotsampasi BM, Menegatos JG, Zervas GP, Kalogiannis DG: Effect of selenium supplementation on thyroid hormone levels and selenoenzyme activities in growing lambs. Biol Trace Elem Res 2006, 109: 145-154.

8. Travnicek J, Pisek, L, Herzig I, Doucha J, Kvicala J, Kroupova V, Rodinova H: Selenium content in the blood serum and urine of ewes receiving selenium-enriched unicellular alga Chlorella. Vet Med-Czech 2007, 52: 42-48.

9. Guyot H, Oliveira LA, Ramery E, Beckers JF, Rollin F: Effect of a combined iodine and selenium supplementation on I and Se status of cows and their calves: J Trace Elem Med Biol 2011, 25: 118-124.

10. Travnicek J, Kroupova V, Konecny R, Stankova M, Stastna J, Hasonova L, Mikulova, M: Iodine status in ewes with the intake of iodine enriched alga Chlorella. Czech J Anim Sci 2010, 55: 58-65.

11. Qin SY, Gao JZ, Huang KH: Effects of different selenium sources on tissue selenium concentrations, blood GSH-Px activities and plasma interleukin levels in finishing lambs. Biol Trace Elem Res 2007, 116: 91-102.

12. Stewart WC, Bobe G, Pirelli GJ, Mosher WD, Hall JA: Organic and inorganic selenium: III. Ewe and progeny performance. J Anim Sci 2012, 90: 4536-4543.

13. Panev A, Hauptmanova K, Pavlata L, Pechova A, Filipek J, Dvorak R: Effect of supplementation of various selenium forms and doses on selected parameters of ruminal fluid and blood in sheep. Czech J Anim Sci 2013, 58: 37-46.

14. Voudouri AE, Chadio SE, Menegatos JG, Zervas GP, Nicol F, Arthur JR: Selenoenzyme activities in selenium- and iodine-deficient sheep. Biol Trace Elem Res 2003, 94: 213-224.

15. Doucha J, Livansky K: Process of outdoor thinlayer cultivation of microalgae and bluegreen algae and bioreactor for performing the process. US Patent 5981271 A, 1999.

16. Kvicala J, Zamrazil V, Soutorova M, Tomisek F: Correlations between parameters of body selenium status and peripheral thyroid parameters in the low selenium region. Analyst 1995, 120: 959-965.

17. Bednar J, Rohling S, Vohnout S: Contribution to the determination of protein iodine in blood serum (in Czech). Cesk Farm 1964, 13: 203-209.

18. Stowe HD, Herdt TH: Clinical-Assessment of Selenium Status of Livestock. J Anim Sci 1992, 70: 3928-3933.

19. Underwood EJ, Suttle N: Selenium. In: The mineral nutrition of livestock. The mineral nutrition of livestock, 3rd ed. (reprinted with corrections). Wallington, United Kingdom: CAB International; 1999, 421-477

20. NRC (National Research Council): Nutrient requirements of sheep, 6 th rev. edn., Washington DC, USA National Academy Press; 1985, 2-25.

21. Aghwan ZA, Sazili AQ, Alimon AR, Goh YM, Hilmi M: Blood Haematology, Serum Thyroid Hormones and Glutathione Peroxidase Status in Kacang Goats Fed Inorganic Iodine and Selenium Supplemented Diets. Asian Australas Anim Sci 2013, 26: 1577-1582.

22. Ghany-Hefnawy AE, López-Arellano R, Revilla-Vázquez A, Ramírez-Bribiesca E, TórtoraPérez J: The relationship between fetal and maternal selenium concentrations in sheep and goats. Small Rumin Res 2007, 73: 174-180.

23. Xu J, Liu XL, Yang XF, Guo HL, Zhao LN, Sun XF: Supplemental Selenium Alleviates the Toxic Effects of Excessive Iodine on Thyroid. Biol Trace Elem Res 2011, 141: 110-118. 
24. Awadeh FT, Kincaid RL, Johnson KA: Effect of level and source of dietary selenium on concentrations of thyroid hormones and immunoglobulins in beef cows and calves. J Anim Sci 1998, 76: 1204-1215.

25. Bik DE: Influence of selenium and iodine supplementation on thyroid hormone concentrations in the blood serum of sheep. Medycyna Wet 2003, 59: 1126-1129.

26. Qin F, Zhu X, Zhang W, Zhou J, Zhang S, Jia Z: Effects of Dietary Iodine and Selenium on Nutrient Digestibility, Serum Thyroid Hormones, and Antioxidant Status of Liaoning Cashmere Goats. Trace Elem Res 2011, 143: 1480-1488.

27. Wichtel JJ, Thompson KG, Craigie AL, Williamson NB: Effects of selenium and iodine supplementation on the growth rate, mohair production, and thyroid status of Angora goat kids. New Zeal J Agr Res 1996, 39: 111-115.

28. Head WA Jr., Hatfield PG, Hallford DM, Fitzgerald JA, Petersen MK, Stellflug JN: Effect of selection for lifetime production of lamb weaned on hormonal factors that affect growth in Targhee ewes and lambs. J Anim Sci 1996, 74: 2152-2157.

29. Hefnawy AE, Youssef S, Aguilera PV, Rodríguez CV, Pérez JLT: The relationship between Selenium and T3 in selenium supplemented and nonsupplemented ewes and their lambs. Vet Med Int 2014

30. Dusova H, Travnicek J, Svoboda M, Banoch T, Kroupova V, Peksa Z, Konecny R: The impact of high iodine intake on thyroid function in ewes and lambs. Neuro Endocrinol Lett 2012, 33: 517-524.

31. Kumar N, Garg AK, Dass RS, Chaturvedi VK, Mudgal V, Varshney VP: Selenium supplementation influences growth performance, antioxidant status and immune response in lambs. Anim Feed Sci Technol 2009, 153: 77-87.

\title{
EFEKTI SUPLEMENTACIJE ORGANSKIM SELENOM I JODOM NA STATUS SELENA I TIREOIDNIH HORMONA OVACA U LAKTACIJI I NJIHOVE JAGNJADI
}

\author{
KONEČNÝ Roman, HASOŇOVÁ Lucie, TRÁVNÍČEK Jan, SAMKOVÁ Eva, \\ HLADKÝ Jan, KŘÍŽOVÁ Zuzana
}

Cilj ispitivanja je bio da se odredi uticaj istovremene suplementacije tokom 56 dana (od 4-og do 60-og dana post partum) selenom (Se) i jodom (I) obogaćenim Chlorella algama, na koncentraciju selena u krvi i urinu i na nivo tireoidnih hormona kod ovaca i njihove jagnjadi. U studiju je bilo uključeno ukupno 18 Šumava ovaca i njihove jagnjadi podeljenih u tri grupe (CON, Hse, HseI). Sadržaj selena i joda u ishrani je iznosio: 0,2 i 0,7 mg (CON), 0,4 i 0,7 mg (HSe), 0,4 i 1,3 mg (HSeI) po kg suve materije. Tokom oglednog perioda signifikantno više koncentracije Se u krvi $(\mathrm{P}<0,001)$ i urinu $(\mathrm{P}<0,01)$ su izmerene kod ovaca u HSeI grupi. Signifikantno više koncentracije Se u serumu $(\mathrm{P}<0,001)$ su izmerene kod jagnjadi u HSeI grupi. Najviša vrednost koncentracije Se u krvi izmerena je kod ovaca $(128,0 \mu \mathrm{g} / \mathrm{L})$ i jagnjadi $(74,2 \mu \mathrm{g} / \mathrm{L}) 26$-tog dana ogleda. Rezultati pokazuju viši stepen iskoristljivosti organski vezanog Se istovremeno aplikovanog sa organski vezanim I. Nivoi tireoidnih hormona u plazmi ovaca se nisu 
eksplicitno menjali pri višoj suplementaciji selenom i jodom. Više vrednosti koncentracije Se u krvnom serumu jagnjadi su dovele do signifikantno $(P<0,05)$ viših nivoa T3 do 30-og dana nakon rođenja. 